\title{
EVALUASI KUALITAS APARAT PENGAWAS INTERN PEMERINTAH DALAM PENGAWASAN KEUANGAN DAERAH (Studi pada Pemerintah Daerah Kabupaten Minahasa Tenggara)
}

\author{
Josua H.R.Lumbantobing \\ Lidya Mawikere
}

\author{
Fakultas Ekonomi dan Bisnis Magister Akuntansi \\ Universitas Sam Ratulangi Manado \\ Email: josua_lumbantobing@yahoo.com
}

\begin{abstract}
This study aimed to evaluate the quality of Government Internal Supervisory Apparatus (APIP) Southeast Minahasa Regency. A common problem in this study is the finding of the audit that is not detected by the APIP as internal auditor, but was found by the external auditor, the Supreme Audit Agency (BPK).

The method used in this research is descriptive qualitative. As in qualitative research, the authors use the method of in-depth interviews and Forum Group of Discussion with informants who have knowledge related to this research.

The results show, that became important points APIP quality analysis Southeast Minahasa Regency are: First, to meet the needs of APIP competent to provide technical guidance, education and ongoing training to improve quality. Second, do not do that too frequent mutation, a mutation that is done must be in accordance with competence. While that is key to improving the quality of APIP is a strong commitment from the Head of Region for the creation of good and clean government to the fulfillment of the budget for APIP by $1 \%$ in accordance with the Regulatory applicable to improving the quality of APIP to provide technical guidance and education and training sustainable, adding facilities such as office operational vehicles and other supporting infrastructure.

Keywords: Quality Evaluation of Internal Control Government officials, government officials Internal Control, Internal Control Apparatus Southeast Minahasa regency government.
\end{abstract}

\section{PENDAHULUAN}

Tuntutan pelaksanaan akuntabilitas sektor publik terhadap terwujudnya good governance dan clean governance di Indonesia semakin meningkat. Tuntutan ini memang wajar, karena beberapa penelitian menunjukkan bahwa terjadinya krisis ekonomi di Indonesia ternyata disebabkan oleh buruknya pengelolaan (bad governance) dan buruknya birokrasi (Sunarsip, 2001).Banyaknya faktafakta yang terungkap tentang kinerja pemerintah yang bisa dinilai kurang memuaskan, mulai dari pengungkapan kasus-kasus korupsi hingga penganggaran yang diluar batas wajar, membuat tuntutan terhadap akuntabilitas sektor publik sangatlah tinggi.

Menurut Mardiasmo (2008), terdapat tiga aspek utama yang mendukung terciptanya kepemerintahan yang baik (good governance), yaitu pengawasan, pengendalian, dan pemeriksaan. Pengawasan merupakan kegiatan yang dilakukan oleh pihak di luar eksekutif, yaitu masyarakat dan Dewan Perwakilan Rakyat Daerah (DPRD) untuk mengawasi kinerja pemerintahan.Pengendalian (control) adalah mekanisme yang dilakukan oleh eksekutif untuk menjamin bahwa sistem dan kebijakan manajemen dilaksanakan dengan baik sehingga tujuan organisasi dapat tercapai.Sedangkan pemeriksaan (audit) merupakan kegiatan yang dilakukan oleh pihak yang memiliki independensi dan memiliki kompetensi professional untuk memeriksa apakah hasil kinerja pemerintah telah sesuai dengan standar yang ditetapkan.

Salah satu unit yang melakukan audit/pemeriksaan terhadap pemerintah daerah adalah Aparat Pengawas Intern Pemerintah(APIP). Menurut Falah (2005) dalam, APIP mempunyai tugas menyelenggarakan kegiatan pengawasan umum pemerintah daerah dan tugas lain yang diberikan kepala daerah, sehingga dalam tugasnya APIPsama dengan auditor internal. Audit internal adalah audit 
yang dilakukan oleh unit pemeriksa yang merupakan bagian dari organisasi yang diawasi (Mardiasmo, 2005).

Peran dan fungsi Aparat Pengawas Intern Pemerintah (APIP) Provinsi, Kabupaten/Kota secara umum diatur dalam pasal 4 Peraturan Menteri Dalam Negeri No 64 Tahun 2007. Dalam pasal tersebut dinyatakan bahwa dalam melaksanakan tugas pengawasan urusan pemerintahan, APIP Provinsi, Kabupaten/Kota mempunyai fungsi sebagai berikut: pertama, perencanaan program pengawasan; kedua, perumusan kebijakan dan fasilitas pengawasan; dan ketiga, pemeriksaan, pengusutan, pengujian, dan penilaian tugas pengawasan.

Audit pemerintahan merupakan salah satu elemen penting dalam penegakan good government.Namun demikian, praktiknya sering jauh dari yang diharapkan. Mardiasmo (2000) menjelaskan bahwa terdapat beberapa kelemahan dalam audit pemerintahan di Indonesia, di antaranya tidak tersedianya indikator kinerja yang memadai sebagai dasar pengukur kinerja pemerintahan baik pemerintah pusat maupun daerah dan hal tersebut umum dialami oleh organisasi publik karena output yang dihasilkan yang berupa pelayanan publik tidak mudah diukur. Dengan kata lain, ukuran kualitas audit masih menjadi perdebatan.

Kualitas audit menurut De Angelo yang dikutip Alim dkk. (2007) adalah sebagai probabilitas bahwa auditor akan menemukan dan melaporkan pelanggaran pada sistem akuntansi klien. Probabilitas untuk menemukan pelanggaran tergantung pada kemampuan teknis auditor dan probabilitas melaporkan pelanggaran tergantung pada independensi auditor. Dengan kata lain, kompetensi dan independensi dapat mempengaruhi kualitas audit.

Dalam sektor publik, Government Accountability Office (GAO), mendefinisikan kualitas audit sebagai ketaatan terhadap standar pofesi dan ikatan kontrak selama melaksanakan audit (Lowenshon, et al, 2005). Pendapat yang sama juga dikemukakan oleh Ikatan Akuntan Indonesia (IAI), yaitu bahwa audit yang dilakukan auditor dikatakan berkualitas jika memenuhi standar auditing dan standar pengendalian mutu (Elfarini, 2005).

Pentingnya standar bagi pelaksanaan audit juga dikemukakan oleh Pramono (2003). Dikatakan bahwa produk audit yang berkualitas hanya dapat dihasilkan oleh suatu proses audit yang sudah ditetapkan standarnya. Lebih lanjut dijelaskan bahwa proses audit dapat dikatakan telah memenuhi syarat quality assurance apabila proses yang dijalani tersebut telah sesuai dengan standar, antara lain: standar for the professional practice, internal audit charter, kode etik internal audit, kebijakan, tujuan, dan prosedur audit, serta rencana kerja audit.

Menurut Peraturan Menteri Negara Pendayagunaan Aparatur Negara nomor PER/05/M.PAN/03/2008, pengukuran kualitas audit atas laporan keuangan, khususnya yang dilakukan oleh APIP, wajib menggunakan Standar Pemeriksaan Keuangan Negara (SPKN) yang tertuang dalam Peraturan Badan Pemeriksa Keuangan Republik Indonesia Nomor 01 Tahun 2007. Pernyataan standar umum pertama SPKN adalah: "Pemeriksa secara kolektif harus memiliki kecakapan profesional yang memadai untuk melaksanakan tugas pemeriksaan". Dengan Pernyataan Standar Pemeriksaan ini semua organisasi pemeriksa bertanggung jawab untuk memastikan bahwa setiap pemeriksaan dilaksanakan oleh para pemeriksa yang secara kolektif memiliki pengetahuan, keahlian, dan pengalaman yang dibutuhkan untuk melaksanakan tugas tersebut.Oleh karena itu, organisasi pemeriksa harus memiliki prosedur rekrutmen, pengangkatan, pengembangan berkelanjutan, dan evaluasi atas pemeriksa untuk membantu organisasi pemeriksa dalam mempertahankan pemeriksa yang memiliki kompetensi yang memadai.

Audit harus dilaksanakan oleh seseorang atau lebih yang memiliki keahlian dan pelatihan teknis yang cukup sebagai auditor.Auditor harus memiliki dan meningkatkan pengetahuan mengenai metode dan teknik audit serta segala hal yang menyangkut pemerintahan seperti organisasi, fungsi, program, dan kegiatan pemerintahan (BPKP, 1998).Keahlian auditor menurut Tampubolon (2005) dapat diperoleh melalui pendidikan dan pelatihan yang berkelanjutan serta pengalaman yang memadai dalam melaksanakan audit. 
Kompetensi seorang auditor bagai sebuah pedang bagi seorang satria.Semakin tinggi kompetensinya, maka semakin tajam pedang yang dipakainya. Tanpa pedang yang tajam, kecil kemungkinan sang satria akan mampu menebas habis musuh-musuhnya. Tanpa kompetensi yang memadai, kecil kemungkinan seorang pengawas akan mampu menjalankan tugas dan perannya secara efektif.

Kompetensi seseorang dipengaruhi oleh tiga hal, yaitu Pengetahuan (knowledge), Keterampilan (skill), dan Perilaku (attitude).Ungkapan ini tidak banyak berubah sejak masa lalu hingga masa kini. Yang berubah adalah substansi materi pengetahuan, keterampilan, dan perilaku apa yang harus dimiliki agar sesuai kompetensi yang dibutuhkan saat menjalankan tugas dan fungsinya. Demikian halnya dengan aparat pengawasan intern, perubahan peran, fungsi, serta dimensi penugasan menuntut aparat pengawasan intern untuk selalu mengasah dan meng-update knowledge, skill, dan attitudenya.

Kompetensi seorang auditor diuji dari pengetahuan dan pengalaman yang dimiliki (Sri Lastanti, 2005:88). Seorang auditor harus memiliki pengetahuan yang diukur dari seberapa tinggi pendidikan seorang auditor, karena dengan demikian auditor akan mempunyai semakin banyak pengetahuan (pandangan) mengenai bidang yang digelutinya sehingga dapat mengetahui berbagai masalah secara makin mendalam. Seorang auditor juga harus berpengalaman dalam melakukan audit.Semakin lama auditor melakukan pemeriksaan maka semakin banyak pengalaman yang dimiliki sebagai seorang auditor.Pengalaman kerja sebagai seorang auditor hendaknya memiliki keunggulan dalam mendeteksi kesalahan, memahami kesalahan secara mendalam, dan mencari penyebab masalah tersebut.

Kualitas audit sebagai proses dimana seorang auditor harus menemukan dan melaporkan pelanggaran dalam sistem akuntansi dengan pengetahuan dan keahlian auditor (Kusharyanti, 2003:25). Untuk menghasilkan kualitas audit yang baik, seorang auditor harus memiliki kompetensi dan juga independensi. Kompetensi seorang auditor sangat dibutuhkan dalam melakukan audit.

Kompetensi merupakan standar yang harus dipenuhi oleh seorang auditor untuk dapat melakukan audit dengan baik. Namun, belum tentu auditor yang memiliki hal di atas akan memiliki komitmen untuk melakukan audit dengan baik. Sebagaimana dikatakan oleh Goleman (2001), hanya dengan adanya motivasi maka seseorang akan mempunyai semangat juang yang tinggi untuk meraih tujuan dan memenuhi standar yang ada. Dengan kata lain, motivasi akan mendorong seseorang, termasuk auditor, untuk berprestasi, komitmen terhadap kelompok serta memiliki inisiatif dan optimisme yang tinggi.

Fenomena tersebut mendorong penulis untuk melakukan penelitian dengan judul : "Evaluasi kualitas Aparat Pengawas Intern Pemerintah (APIP) dalam pengawasan keuangan daerah Pemerintah Kabupaten Minahasa Tenggara".

Sehubungan dengan audit pemerintah, terdapat penelitian mandiri mengenai pengaruh rewards instrumentalities dan environmental risk factors terhadap motivasi partner auditor independen untuk melaksanakan audit pemerintah. Penghargaan (rewards) yang diterima auditor independen pada saat melakukan audit pemerintah dikelompokkan ke dalam dua bagian penghargaan, yaitu penghargaan intrinsik (kenikmatan pribadi dan kesempatan membantu orang lain) dan penghargaan ekstrinsik (peningkatan karir dan status). Sedangkan faktor risiko lingkungan (environmental risk factors) terdiri dari iklim politik dan perubahan kewenangan.

Arens, et.al.(2000) mendefinisikan independensi dalam pengauditan sebagai "Penggunaan cara pandang yang tidak bias dalam pelaksanaan pengujian audit, evaluasi hasil pengujian tersebut, dan pelaporan hasil temuan audit". Sedangkan Mulyadi (1992) mendefinisikan independensi sebagai "keadaan bebas dari pengaruh, tidak dikendalikan oleh pihak lain, tidak tergantung pada orang lain" dan akuntan publik yang independen haruslah akuntan publik yang tidak terpengaruh dan tidak dipengaruhi oleh berbagai kekuatan yang berasal dari luar diri akuntan dalam mempertimbangkan fakta yang dijumpainya dalam pemeriksaan.

Alim dkk (2007) melakukan penelitian kualitas audit yang dilakukan oleh auditor pada kantor Akuntan Publik se-Jawa Timur. Variabel penelitian yang digunakan yaitu kompetensi dan 
independensi sebagai variabel independen, kualitas audit sebagai variabel dependen, dan etika auditor sebagai variabel moderasi. Dari penelitian tersebut diketahui bahwa independensi dan kompetensi auditor berpengaruh signifikan terhadap kualitas audit.

Hasil penelitian yang dilakukan oleh Murtanto (1998) dalam Mayangsari (2003) menunjukkan bahwa komponen kompetensi untuk auditor di Indonesia terdiri atas:

1) Komponen pengetahuan, yang merupakan komponen penting dalam suatu kompetensi. Komponen ini meliputi pengetahuan terhadap fakta-fakta, prosedurprosedur dan pengalaman.

2) Ciri-ciri psikologi, seperti kemampuan berkomunikasi, kreativitas, kemampuan bekerjasama dengan orang lain. Gibbin's dan Larocque's (1990) juga menunjukkan bahwa kepercayaan, komunikasi, dan kemampuan untuk bekerjasama adalah unsure penting bagi kompetensi audit.

Muh. Taufig Efendy (2010) meneliti pengaruh kompetensi, independensi, dan motivasi terhadap kualitas audit aparat inspektorat dalam pengawasan keuangan daerah. Diketahui bahwa kompetensi, independensi, dan motivasi secara simultan berpengaruh terhadap kualitas audit yang dilaksanakan oleh aparat Inspektorat Kota Gorontalo. Komponen kompetensi dan motivasi berpengaruh positif terhadap kualitas audit, sedangkan komponen independensi tidak berpengaruh secara signifikan terhadap kualitas audit.

I. A. Angge Septiari dan Edy Sujana meneliti pengaruh kompetensi dan independensi terhadap kualitas audit dengan studi empiris pada 5 kantor inspektorat provinsi bali. Diketahui bahwa Komponen kompetensi berpengaruh positif terhadap kualitas audit, sedangkan komponen independensi tidak berpengaruh secara signifikan terhadap kualitas audit.

\section{METODE PENELITIAN}

Berdasarkan pada jenis dan sumber data serta teknik pengumpulan data maka, penelitian ini menggunakan metode analisis deskriptif kualitatif dengan teknik analisis perbandingan antara indikator yang telah ditentukan dengan jawaban yang diberikan berdasarkan kondisi aktual di lapangan.Sehingga menghasilkan suatu penelitian deskriptif kualitatif yang menjelaskan dan menggambarkan situasi aktual pada objek penelitian. Indikator-indikator tersebut dihasilkan atas dasar teori yang ada sehingga mampu dipertanggungjawabkan deskriptif atau penjelasan yang akan dibuat oleh peneliti.

Peneliti telah mengambil data langsung dari responden dengan menggunakan metode wawancara langsung (direct interview) dan Forum Group of Discussion (FGD) berdasarkan daftar pertanyaan yang dibagikan kepada Aparat Pengawas Intern Pemerintah, anggota pemeriksa BPK atas APIP Kabupaten Minahasa Tenggara.

Pada penelitian ini, teknik wawancara yang digunakan adalah wawancara secara personal (personally direct interview). Wawancara ini terdiri dari tiga bagian, yaitu surat permohonan wawancara, data responden, dan daftar pertanyaan. Dalam hal ini Inspektorat Daerah Pemerintah Kabupaten Minahasa Tenggara merupakan lokasi penelitian atau merupakan objek penelitian yang dilakukan oleh penulis.

\section{PEMBAHASAN}

Kualitas audit aparat Inspektorat di Kabupaten Minahasa Tenggara masih belum memadai karena selama berdirinya Kabupaten ini, Laporan Hasil Pemeriksaan Badan Pemeriksa Keuangan Republik Indonesia Perwakilan Sulawesi Utara dari tahun 2008 sampai dengan 2012 selalu menghasilkan opini tidak memberikan pendapat (disclaimer). Opini Tidak Memberikan Pendapat (disclaimer) yang diperoleh selama 5 (lima) tahun berturut-turut tersebut antara lain disebabkan oleh permasalahan yang berulang diantaranya mengenai pengelolaan pajak, pengelolaan belanja barang dan jasa, pengelolaan belanja bantuan dan hibah, keterlambatan penyelesaian pekerjaan, pengelolaan aset tetap, pengelolaan piutang, pengelolaan pendapatan asli daerah, pengelolaan kas, pengelolaan belanja modal, pengelolaan utang, pengelolaan belanja pegawai, dan pengelolaan persediaan.

Kompetensi aparat Inspektorat Kabupaten Minahasa Tenggara sampai dengan saat ini masih perlu banyak pembenahan. Auditor yang berkompeten seharusnya mengetahui dan memahami bahwa 
sesungguhnya Kertas Kerja Pemeriksaan (KKP) adalah merupakan alat untuk mengungkapkan setiap detail akun-akun yang diperiksa. KKP ini merupakan tanggungjawab mutlak dari auditor untuk mengisi informasi detail yang diperlukan dirinya untuk meyakinkan dirinya bahwa akun yang diperiksanya telah disajikan dengan benar dan sesuai dengan aturan yang mengaturnya. Kertas Kerja Pemeriksaan merupakan kewajiban dari pada auditor untuk dibuat dan disimpan dengan baik, agar dikemudian hari apabila ada masalah hukum yang harus dihadapi, auditor dapat mempertanggungjawabkan pekerjaannya sesuai dengan KKP yang dia buat. Laporan Hasil Pemeriksaan yang akan disampaikan kepada auditan seharusnya direviu terlebih dahulu secara berulang-ulang dan berjenjang mulai dari ketua tim, Irban, Sekretaris Inspektorat hingga Inspektur sebelum dia menandatanganinya sehingga kesalahan-kesalahan yang tidak perlu dapat diminimalisasi.

Inspektorat Kabupaten Minahasa Tenggara selaku APIP mempunyai tugas pokok dan fungsi dalam bidang pengawasan yang kegiatannya antara lain audit dan reviu Laporan Keuangan. Untuk mendukung tugas dan fungsi tersebut Inspektorat harus memiliki jumlah dan kompetensi tenaga pengawas yang memadai dan diberikan pendidikan dan pelatihan berkelanjutan yang sesuai kebutuhan.

Efektivitas kegiatan audit dan reviu Laporan Keuangan (LK) Aparat Pengawasan Intern Pemerintah (APIP) pada Inspektorat Kabupaten Minahasa Tenggara yang salah satu tujuannya adalah untuk menilai efektivitas struktur dan tata kelola yang mendukung fungsi audit dan reviu LK. Salah kriteria yang dibangun adalah bahwa struktur dan tata kelola APIP yang mendukung fungsi audit dan reviu LK harus memadai dengan satu sub kriteria yang digunakan adalah sumber daya pendukung yang memadai. Sumber daya dimaksud adalah jumlah tenaga pengawas (auditor/P2UPD) tersedia dan telah dihitung berdasarkan analisis kebutuhan, kompetensi tenaga pengawas (auditor/P2UPD) sesuai persyaratan dan tenaga pengawasan (auditor/P2UPD) telah mendapatkan pendidikan dan pelatihan yang berkelanjutan sesuai kebutuhan.

Berdasarkan wawancara peneliti dengan beberapa orang informan kunci yang menyatakan bahwa Inspektorat Kabupaten Minahasa Tenggara belum mempunyai tenaga pengawas (auditor/P2UPD).Inspektorat Kabupaten Minahasa Tenggara belum menghitung jumlah tenaga pengawas berdasarkan analisis kebutuhan.

Inspektorat Kabupaten Minahasa Tenggara sampai dengan tanggal 30 September 2014 memiliki jumlah pegawai sebanyak 36 orang terdiri dari 29 orang tenaga pengawas dan 7 orang pegawai sekretariat. Berdasarkan analisis perhitungan beban kerja berdasarkan Peraturan Kepala BPKP Nomor KEP-971/K/SU/2005 tentang Pedoman Penyusunan Formasi Jabatan Fungsional Auditor di Lingkungan Aparat Pengawasan Internal Pemerintah diketahui jumlah pegawai yang tersedia pada Inspektorat Kabupaten Minahasa Tenggara tidak sebanding dengan jumlah objek pemeriksaan yang ada. Adapun hasil perhitungan beban diperoleh jumlah ideal auditor dibandingkan dengan jumlah pegawai yang tersedia yang dilakukan oleh Badan Pemeriksa Keuangan dalam Laporan Hasil Pemeriksaan atas Aparat Pengawas Internal Pemerintah (APIP) Inspektorat Kabupaten Minahasa Tenggara sebagai berikut.

Tidak memadainya kompetensi dari tenaga pengawas disebabkan pola mutasi yang terlalu sering yang terjadi pada Inspektorat. Tenaga pengawas yang telah memiliki pengalaman audit dipindahkan dan penggantinya merupakan pegawai yang belum memiliki pengalaman dan latar belakang pendidikan yang tidak tepat dengan bidang pengawasan. Pegawai yang dipindahkan ke Inspektorat tidak mempertimbangkan kompetensi dan latar belakang pendidikan pegawai yang bersangkutan sesuai dengan kebutuhan fungsi pengawasan. Bahkan dalam satu tim, mulai dari Inspektur Pembantu (Irban) Wilayah sampai dengan staf pelaksana baru semua, sehingga kinerja tim tidak maksimal. Bagaimana tim bisa bekerja maksimal apabila mereka tidak tahu apa yang harus mereka lakukan. Karena semua anggota tim baru sehingga entry briefing yang seharusnya dilakukan setiap kali sebelum tim melakukan pemeriksaan/pengawasan tidak berjalan.

Aparat Inspektorat yang dikirim untuk mengikuti bimbingan teknis (bimtek) maupun pendidikan dan latihan (diklat) tidak berkompeten dan serius sehingga hasilnya setelah mereka 
mengikuti bimtek/diklat sama saja seperti sebelum mereka pergi. Mereka mengangap bahwa dikirim mengikuti bimtek/diklat sebagai ajang berekreasi saja.

Inspektur diangkat dan diberhentikan oleh Bupati, karena diangkat dan diberhentikan oleh Bupati, maka independensi Inspektorat itu diragukan. Inspektorat dituntut untuk mengikuti apa maunya Bupati, jika Bupati suruh A, maka Inspektorat harus lakukan sesuai yang Bupati perintahkan.

Independensi aparat pengawas Inspektorat juga tergantung dari kompetensi pengawas itu sendiri.Pengawas yang memiliki kompetensi yang baik hasil dari pembinaan serta pelatihan-pelatihan dengan sendirinya memiliki independensi yang tinggi dalam melaksanakan tugas dan tanggungjawabnya sebagai auditor. Seorang pengawas (auditor) minimal harus setingkat lebih tinggi kemampuannya dibandingkan dengan yang diawasi (auditan), kalau sama maka pengawas dapat dengan mudah ditipu atau dikerjai oleh auditan, karena auditan lebih menguasai apa yang dia kerjakan.Auditor yang tidak berkompeten hanya akan ditertawakan bahkan dipermalukan oleh auditan dengan diberikan informasi yang tidak benar atau bahkan diberikan uang supaya mereka tidak datang lagi melakukan pemeriksaan karena mereka juga tidak tahu apa yang harus mereka lakukan di obrik, sehingga untuk apa berlama-lama disana

Tenaga pengawas yang akan melakukan audit dan reviu laporan keuangan wajib memiliki pengetahuan dan akses atas informasi teraktual dalam standar, metodologi, prosedur, dan teknik audit dan reviu laporan keuangan. Untuk mengembangkan kompetensinya tersebut tenaga pengawas wajib mengikuti pendidikan dan pelatihan berkelanjutan sesuai dengan kebutuhannya.Inspektur selaku pimpinan APIP berkewajiban memfasilitasi pegawai yang ada untuk mengikuti pendidikan dan pelatihan serta ujian sertifikasi sesuai dengan ketentuan. Pendidikan profesional berkelanjutan dapat diperoleh melalui keanggotaan dan partisipasi dalam asosiasi profesi, pendidikan sertifikasi jabatan fungsional auditor, konferensi, seminar, kursus-kursus, program pelatihan di kantor sendiri, dan partisipasi dalam proyek penelitian yang memiliki substansi di bidang audit.Materi dan jumlah jam pendidikan dan pelatihan belum mencukupi karena kurangnya anggaran dan informasi mengenai diklat serta belum disusunnya mekanisme pemberian diklat.

Sarana dan prasarana kerja pemerintahan daerah merupakan faktor penting dalam menunjang terlaksananya kegiatan audit dan reviu laporan keuangan. Sarana dan prasarana yang memadai dapat meningkatkan kinerja dan kelancaran tugas audit dan reviu laporan keuangan agar berdaya guna dan berhasil guna.

BPK melakukan pemeriksaan kinerja atas efektivitas kegiatan audit dan reviu Laporan Keuangan (LK) Aparat Pengawasan Intern Pemerintah (APIP) pada Inspektorat Kabupaten Minahasa Tenggara yang salah satu tujuannya adalah untuk menilai efektivitas struktur dan tata kelola yang mendukung fungsi audit dan reviu LK. Salah kriteria untuk mengukur efektivitas struktur dan tata kelola tersebut adalah Inspektorat dalam melaksanakan audit dan reviu LK harus didukung sumber daya pendukung yang memadai yaitu memadainya peralatan dan ruang kantor yang dibutuhkan untuk menunjang kegiatan audit dan reviu LK.

Berdasarkan observasi fisik yang dilakukan dalam rangka penyediaan sarana dan prasarana Inspektorat yang mendukung kegiatan audit dan reviu laporan keuangan diketahui bahwa Inspektorat telah memiliki fasilitas ruangan kerja yang memadai namun belum menyediakan peralatan kerja minimal yang harus ada sebagai pendukung kegiatan audit maupun reviu laporan keuangan. Inspektorat telah memiliki ruangan kerja yang cukup memadai seperti ruangan kerja lnspektur, para Inspektur Pembantu dan staf, ruangan Sekretaris Inspektorat dan staf, ruangan bendahara dan ruangan rapat.

Terkait kendaraan operasional, para tenaga pengawas tidak diberikan fasilitas tersebut.Dalam kegiatan audit, kendaraan yang digunakan adalah kendaraan pribadi yang dimiliki oleh para tenaga pengawas tanpa diberikan uang sewa kendaraan. Keterangan dari staf pengawas, untuk kendaraan pribadi yang digunakan dalam kegiatan pengawasan hanya diberikan uang untuk pembelian bahan bakar minyak yang jumlahnya tidak tentu setiap kali pelaksanaan audit. 
Inspektorat tidak memiliki sarana prasarana yang digunakan untuk kegiatan pembuatan laporan hasil pemeriksaan dan pemeriksaan fisik pekerjaan seperti komputer, laptop, printer, alat ukur ketebalan aspal (cordrill) dan alat ukur lapisan tembok (hammer test). Berdasarkan Kartu Inventaris Barang (KIB), Inspektorat memiliki sarana dan prasarana pendukung audit dengan keterangan kondisi masih baik berupa 2 unit laptop, 8 unit printer, 7 unit Komputer PC, 1 unit projektor, 1 unit sepeda motor dan 1 unit mobil. Laptop dikuasai oleh Inspektur dan Sekretaris Inspektorat, komputer dan printer terletak di masing-masing ruangan.Jumlah tersebut masih kurang memadai jika dibandingkan jumlah tenaga pengawas yang ada pada Inspektorat.Keterangan dari para tenaga pengawas diketahui bahwa dalam pelaksanaan kegiatan audit, para tenaga pengawas menggunakan laptop pribadi.Kamera sebagai salah satu alat minimal yang harus dipunyai Inspektorat baru diadakan di tahun 2014.

Terkait dengan perolehan informasi mengenai peraturan-peraturan terbaru dan hubungan komunikasi dengan pihak luar terkait kegiatan audit dan reviu laporan keuangan, Inspektorat baru memiliki jaringan internet yang sangat penting dalam mendukung kegiatan tersebut di tahun 2014 .

\section{KESIMPULAN DAN SARAN}

Penelitian ini bertujuan untuk mengetahui kondisi kualitas aparat Inspektorat Kabupaten Minahasa Tenggara dalam menghasilkan audit yang berkualitas pula. Berdasarkan hasil penelitian maka dapat diambil kesimpulan sebagai berikut :

a. Jumlah dan Kompetensi Tenaga Pengawas pada Inspektorat Kabupaten Minahasa Tenggara Kurang dan Belum Mendukung Kegiatan Audit.

b. Kurangnya pemberian bimbingan teknis (bimtek), pendidikan dan pelatihan (diklat) kepada para tenaga pengawas

c. Infrastruktur Penunjang dan Pendukung yang Dimiliki APIP Belum Mendukung Kegiatan Audit dan Reviu Laporan Keuangan.

Sampai dengan selesainya penelitian ini peneliti belum memperoleh rekomendasi dari pihak BPK Perwakilan Provinsi Sulut untuk melakukan wawancara dengan pemeriksa BPK yang melaksanakan pemeriksaan atas kinerja dan efektivitas audit dan reviuw Laporan Keuangan oleh Inspektorat Kabupaten Minahasa Tenggara.

Saran yang diberikan penulis adalah:

a. Mencukupi kebutuhan jumlah pegawai pada bidang pengawasan dengan apa yang ada sekarang dimaksimalkan, dengan mengikutsertakan para pegawai Inspektorat dalam kegiatan bimbingan teknis (bimtek) serta pendidikan dan pelatihan (diklat) baik itu Jabatan Fungsional Auditor (JFA) yang diadakan oleh BPKP sebagai koordinator maupun jabatan fungsional Pejabat Pengawas Urusan Pemerintah Daerah (P2UPD) yang diadakan oleh Inspektorat Jenderal Departemen Dalam Negeri (Itjen Depdagri);

b. Agar Inspektur lebih cermat dalam mengirim pegawai yang akan mengikuti bimtek/diklat, kalau perlu mewajibkan mereka yang dikirim mengikuti bimtek/diklat untuk mempresentasikan hasilnya kepada pegawai yang tidak dikirim.

c. Agar Inspektur sebagai anggota Badan Pertimbangan Jabatan dan Kepangkatan (Baperjakat) melarang apabila staf pengawasnya baik auditor maupun P2UPD dipindahkan ke Satuan Kerja Perangkat Daerah (SKPD) lain, kecuali mereka yang dipromosikan untuk menjabat sekretaris di SKPD lain atau menduduki jabatan eselon 2.

d. Agar Inspektur menginstruksikan Kepala BKDD dalam melakukan pola mutasi pegawai pada Inspektorat Kabupaten Minahasa Tenggara agar memperhatikan kompetensi pegawai.

e. Agar Inspektur Kabupaten Minahasa Tenggara lebih cermat dalam pengadaan sarana dan prasarana pendukung kegiatan audit dan reviu Laporan Keuangan. 


\section{DAFTAR PUSTAKA}

Alim, M.N., T. Hapsari, dan L. Purwanti. 2007. Pengaruh Kompetensi dan Independensi terhadap Kualitas Audit dengan Etika Auditor sebagai Variabel Moderasi.Simposium Nasional Akuntansi $X$. Makassar

Arens, A.A., J.K. Loebbecke. 2008. Auditing: An Integrated Approach. Eight Edition. New Jersey: Prentice Hall International Inc.

BPK. 2013. Laporan Hasil Pemeriksaan Kinerja atas Efektivitas Kegiatan Audit dan Reviu Laporan Keuangan oleh Inspektorat Kabupaten Minahasa Tenggara Tahun Anggaran 2012 dan Semester I Tahun Anggaran 2013.

BPKP.1998. Modul Diklat Peningkatan Kemampuan APFP Provinsi DI Yogyakarta.Unit Pengelola Pendidikan dan Latihan Pengawasan Perwakilan BPKP DI Yogyakarta.

Elfarini, E.C. 2005. Pengaruh Kompetensi dan Independensi Auditor terhadap Kualitas Audit. Skripsi tidak dipublikasikan. Universitas Negeri Semarang

Falah, S. 2005. Pengaruh Budaya Etis Organisasi dan Orientasi Etika terhadap Sensitivitas Etika.Tesis tidak dipublikasikan. Universitas Diponegoro Semarang

Goleman, D. 2001. Working White Emotional intelligence. (terjemahan Alex Tri

Kantjono W). Jakarta : PT Gramedia Pustaka Utama

I. A. Angge Septiari dan Edy Sujana.Pengaruh kompetensi dan independensi Terhadap kualitas audit (studi empiris pada 5 kantor inspektorat provinsi bali)

Kusharyanti. 2003. "Temuan penelitian mengenai kualitas audit dan kemungkinan topik penelitian di masa datang". Jurnal Akuntansi danManajemen (Desember). Hal.25-60

Lowenshon, S., Johnson E.L., dan Elder J.R. 2005.Auditor Specialization and Perceived Audit Quality, Auditee Satisfaction, and Audit Fees in the Local Government Audit Market

Mardiasmo, 2000, Otonomi \& Manajemen Keuangan Daerah, Yogyakarta: Penerbit Andi

Mardiasmo. 2005. Pewujudan Transparansi dan Akuntabilitas Publik Melalui Akuntansi Sektor Publik: Suatu Sarana Good Governance. Jurnal AkuntansiPemerintah Vol. 2, No. 1

Mardiasmo. 2008. Akuntansi Sektor Publik Edisi 4. Penerbit Andi. Yogyakarta

Mayangsari, S. 2003. Pengaruh Keahlian Audit dan Independensi terhadap Pendapat Audit: Suatu Kuasieksperimen. Jurnal Riset Akuntansi Indonesia Vol. 6 No. 1. Januari

Muh. Taufiq Efendy. Pengaruh kompetensi independensi dan motivasiterhadap kualitas audit aparat Inspektorat dalam pengawasan keuangan daerah. Tesis. Universitas Diponogoro. Semarang.

Mulyadi. 1992. Pemeriksaan Akuntan. Yogyakarta: Badan Penerbit STIE YKPN

Peraturan Badan Pemeriksa Keuangan Republik Indonesia Nomor 01 Tahun 2007.Standar

Pemeriksaan Keuangan Negara. Jakarta

Peraturan Menteri Negara Pendayagunaan Aparatur Negara nomor PER/05/M.PAN/03/2008.Standar Audit Aparat Pengawasan InternPemerintah. Jakarta.

Peraturan Bupati Minahasa Tenggara Nomor 05 Tahun 2009.Tentang Penjabaran Tugas Pokok Dan Fungsi Inspektorat Kabupaten Minahasa Tenggara. Sulawesi Utara.

Pramono, E.S. 2003. Transformasi Peran Internal Auditor dan Pengaruhnya bagi Organisasi.Media Riset Akuntansi, Auditing \& Informasi Vol. 3 No.2 Agustus

Samelson, D., Lowenshon, S., and Johnson, L. 2006.The Determinants of Perceived Audit Quality and Auditee Satisfaction in Local Government. Journal of Public Budgeting, Accounting, \& Financial Management, Vol. 18, No. 2

Sri Lastanti, Hexana. 2005. Tinjauan Terhadap Kompetensi dan Independensi Akuntan Publik : Refleksi Atas Skandal Keuangan. Media Riset Akuntansi, Auditing dan Informasi Vol.5 No.1 April 2005.

Sunarsip, 2001, Coorporat Governance Audit : Paradigma Baru Profesi Akuntansi dalam Mewujudkan Good Coorporate Gvernance, Media Akuntansi, No. 17/Th. VII.pp. II-VII 
Tampubolon, R. 2005. Risk and Systems-Based Internal Audit.Penerbit Elex Media Komputindo. Jakarta

Undang-Undang No. 9 Tahun 2007 tanggal 6 Januari 2007. Pembentukan Kabupaten Minahasa Tenggara.

Gambar 4.1. Struktur Organisasi APIP Kabupaten Minahasa Tenggara

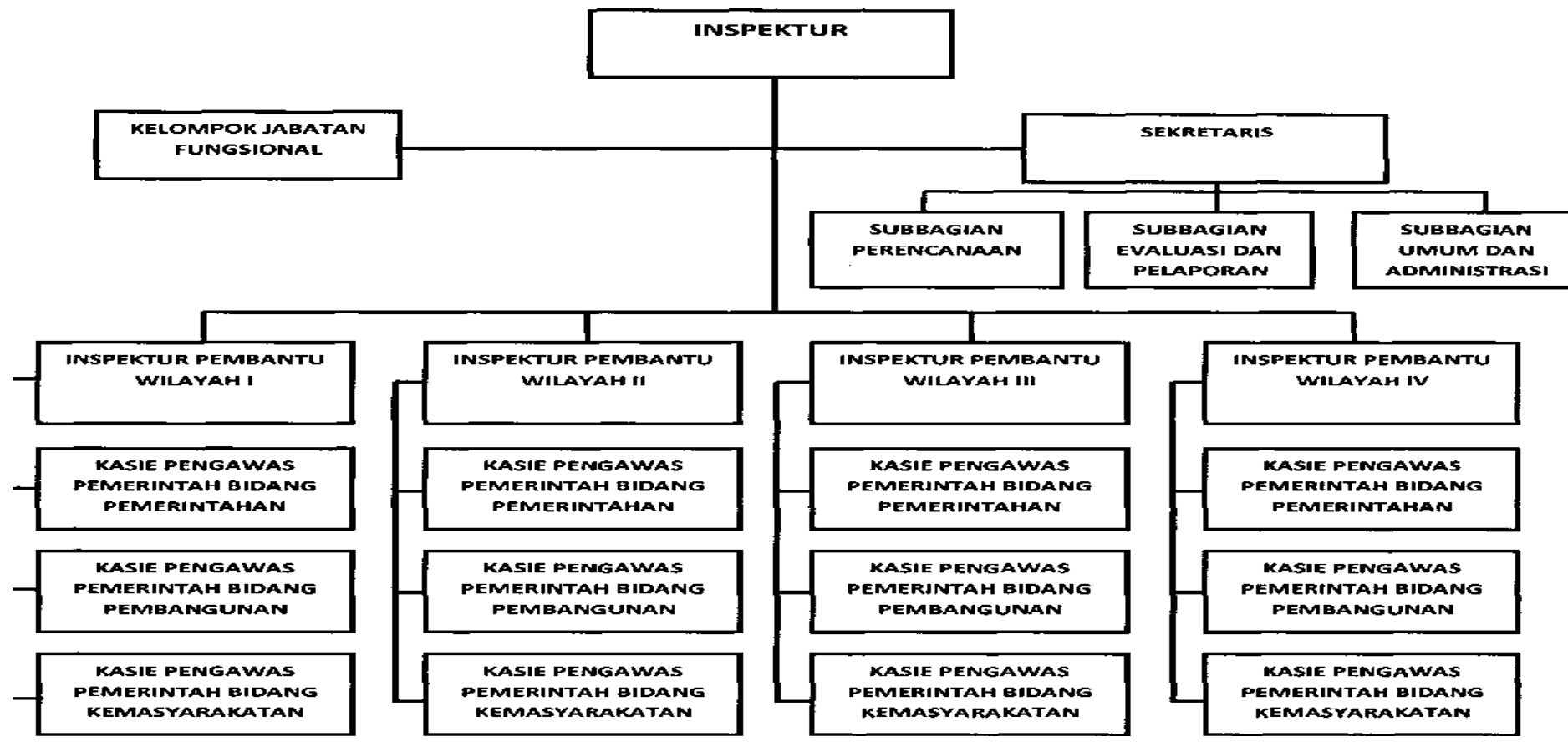

Tabel 4.1. Hasil Perhitungan Analisis Beban Kerja Rincian perhitungan pada lampiran

\begin{tabular}{|c|l|c|r|r|}
\hline No & Jabatan & Kebutuhan & $\begin{array}{c}\text { Jumlah } \\
\text { Yang ada }\end{array}$ & Selisih \\
\hline 1 & Auditor Ahli Utama/P2UPD Utama & 1 & 0 & -1 \\
\hline 2 & Auditor Ahli Madya/P2UPD Madya & 2 & 0 & -2 \\
\hline 3 & Auditor Ahli Muda/P2UPD Muda & 6 & 0 & -6 \\
\hline 4 & Auditor Ahli Pertama/ Auditor Terampil/P2UPD Pertama & 18 & 0 & -18 \\
\hline 5 & Non Auditor/Non P2UPD & 0 & 29 & 29 \\
\hline \multicolumn{2}{|c|}{ Jumlah } & $\mathbf{2 7}$ & $\mathbf{2 9}$ & $\mathbf{2}$ \\
\hline
\end{tabular}

Tabel 4.2. Komposisi SDM Berdasar Latar Belakang Pendidikan

\begin{tabular}{|c|l|r|}
\hline No. & \multicolumn{1}{|c|}{ Bidang pendidikan } & Jumlah \\
\hline 1 & Akuntansi & 8 \\
\hline 2 & Ekonomi & 8 \\
\hline 3 & Hukum & 2 \\
\hline 4 & Teknik & 6 \\
\hline 5 & Ilmu Kepemerintahan & 3 \\
\hline 6 & Komunikasi & 1 \\
\hline 7 & Pendidikan & 6 \\
\hline
\end{tabular}




\begin{tabular}{|l|l|r|}
\hline 8 & Sastra & 1 \\
\hline 9 & Lain & 1 \\
\hline
\end{tabular}

Tabel 4.3. Anggaran dan Realisasi Kegiatan Pendidikan dan Pelatihan

\begin{tabular}{|c|r|r|r|}
\hline Tahun & Anggaran (Rp) & Realisasi (Rp) & Persentase \\
\hline 2012 & $72.500 .000,00$ & $72.225 .000,00$ & 99,62 \\
\hline 2013 & $123.500 .000,00$ & & - \\
\hline 2014 & $102.000 .000,00$ & $82.500 .000,00$ & 80,88 \\
\hline
\end{tabular}

